\title{
凝集塊のある濃厚血小板の機能について
}

\author{
坂内誠松田利夫 \\ 東京都赤十字血液センター
}

（昭和62年 6 月 9 日受付）

\section{THE FUNCTION OF PLATELET CONCENTRATES CONTAINING AGGREGATES}

\author{
Makoto Bannai and Toshio Mazda \\ Japanese Red Cross Tokyo Metropolitan Blood Center
}

Platelet size distribution and aggregation response were studied in platelet concentrates (PCs) containing platelet aggregates. Both normal and abnormal platelet size distribution were observed. As the number of clumps in PC increased, abnormal size distribution patterns also increased. As size distribution became abnormal, aggregability to thrombin decreased. Passage of PC through microaggregate filters did not affect platelet functions.

These in vitro results indicate that some PCs, containing platelet aggregates can be used for transfusions while others can not. The selection of the proper PC can be judged by the number of clumps, and more exactly, by platelet size distribution. PCs of normal size distribution can be used for transfusion provided adequate blood filters are employed.

\section{序言}

濃厚血小板 $(\mathrm{PC})$ の調製にあたり，血小板が再 浮遊せず血小板の凝集塊がみられることがあ る ${ }^{1)}$ ここの再浮遊をしない $\mathrm{PC}$ の発生は $\mathrm{pH}$ が高い 場合に起きることから，抗凝固剤の $\mathrm{ACD}$ 液を過 剩に加えることにより，pH を下げて PCを調製 することが試みられ，その結果，凝集塊の生成が 扣さ兄られ輸血後の Yield が良くなるといら報告 がある23). しかし， $\mathrm{pH}$ の低下はクリオプレシピ テートの調製などに悪影響を与えること文), さら に PC の長期保存にも問題があること的などから 実施させず, 遠心後に静置し》), 時間を置くことに より,血小板周囲の $\mathrm{pH}$ を低下させ每凝集塊の発生 をできるだけ防止するようにしている。

日本では1983年に抗凝固剂が $\mathrm{ACD}$ 液から $\mathrm{CPD}$ 液に変り $\mathrm{PC}$ 中の凝集塊の発生率が若干上 昇した ${ }^{1)}$.このような凝集塊のある $\mathrm{PC}$ は輸血して も患者の血小板数が上昇しないと言われている4) ので, 血液センターでは, このような PC は供給し ていない。一方, 1985年には PC の有効時間が 48 時 間にまで延長されたが，それにもかかわらず医療
機関が集中している東京都内では，需要に応じき れないことがある9．そこで今回はこのような凝 集塊のみられる PCでも，ぞらしても血小板輸血 を必要とする場合，輸血用として使用できるのか どらかを検討するため，凝集塊の量と血小板の粒 度分布（血小板体積分布）との関係，さらにそれ らと血小板機能について比較検討した。 そして, 輸血に際し，凝集塊を取除くため Microaggregate Filterを用いた場合，その血小板機能へ の影響を検討した。

その結果，凝集塊のある $\mathrm{PC}$ にも使用できると 思われるものと，そらでないものがあることそそ して，それを粒度分布を測定することにより簡単 に見分けられることがわかった。さらに，Microaggregate Filterを用いれば血小板の品質に 影響を与兄ずに凝集塊を除去できることがわかっ たので報告する。

\section{方 法}

\section{PC の調製}

献血者より, $220 \mathrm{~m} l$ の血液を $\mathrm{CPD}$ 液 $28 \mathrm{~m} l$ 入り トリプルバック（Teruflex，テルモ製）に採血し， 
IEC DPR-6000遠心機を用い，4 時間以内に PC を 調製した ${ }^{10)}$. 全血より多血小板血浆 (PRP) を $1,100 \times \mathrm{g}(2,000 \mathrm{rpm}), 22^{\circ} \mathrm{C}, 6$ 分間の遠心で調 製し，さらに，3,350× g (3,500rpm)， 7 分の遠 心で血小板を沈澱させた。 上清血浆を約 $20 \mathrm{~m} l$ 残 して取り除き, $22^{\circ} \mathrm{C} て ゙ 1.5 \sim 2$ 時間静置後, $22^{\circ} \mathrm{C}$ で 垂直回転(PA-18, Helmer 製, 6rpm)で保存した。 15時間後，PCを肉眼により凝集塊の有無を判定 し, さらに, 血小板の粒度分布，扣よび血小板凝 集能の測定を行った。

2. 凝集塊の判定および Microfiltration

$\mathrm{PC}$ 中の凝集塊は肉眼的に 3 群に分類した. 直 径 $1 \mathrm{~mm}$ 以上の凝集塊の数が $1 \sim 2$ 個のもの を+, $3 \sim 9$ 個のものを\#, 10個以上のものを世 とした。

血小板への Microaggregate Filter の影響を見 るには，調製・静置後，水平回転 $(M R-5$, カヤガ キ製，50rpm)の擋汼で15時間保存した PCを用い て Microaggregate Filter (MF10，カワスミ製) に通し, 透過前後の血小板数, 粒度分布, 平均血 小板体積 (MPV)，凝集能の測定を行った。

3. 粒度分布の測定

粒度分布と血小板数及び MPV は PC を希釈液 （セルェント，東亜医用電子製）により10,000倍に 希釈し, すみやかに血球計数器 (CC-108, 東亜医 用電子製）と接続した粒度分布記録装置（PDA400, 東亜医用電子製)で測定した。体積調製は 4.3 $\mu \mathrm{m}^{3}$ のラテックス粒子を用いた。最小閾値は2.5 $\mu \mathrm{m}^{3}$ に設定した。

\section{4. 凝集能の測定}

Adenosin diphosphate(ADP，シグマ製, Grade I), コラーゲン (Horm 製) に対する最大凝集能, およびトロンビン（シグマ製，850-1）に対する試 薬添加 5 分後の最大凝集能を, あるいはこれらを 複合して添加したときの最大凝集能を凝集計 (Hema Tracer 1, Model PAT-4A, 二光バイオ

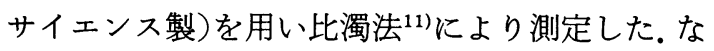
お，トロンビンあるいはそれと他の凝集惹起物質 を同時に使用する場合は, 測定は Legrand らの方 法 ${ }^{12)}$ で 1 回洗浄した血小板を用いた。 また, 洗浄血 小板を用いて ADP (単独)に対する凝集能を測定
する場合には, $\mathrm{ADP}$ の他に $0.2 \mathrm{mg} / \mathrm{m} l$ フィブリ ノゲン（Grade L，Kabi 製）を添加した。

\section{結 果}

通常, $\mathrm{PC}$ 中の血小板の粒度分布は $5 \sim 6 \mu \mathrm{m}^{3}$ に ピークを持つ曲線（Fig. 1, Type 1) を描くが, 中には小粒子の割合が異常に増えた粒度分布 (Type 3) を示すものと，その中間型（Type 2) を示すものの 3 群に分類できた。

凝集塊のみられないPC (一)では汪とんどが正 常な粒度分布（Type 1）を示したが，凝集塊のあ る $\mathrm{PC}$ の粒度分布は様々で, 肉眼判定による凝集 塊の多いPC ほど，粒度分布では小粒子の割合が 増加したものが多かった (Table 1). 肉眼判定世 のPCでは70\%が Type 3に分類され, Type 1は ほとんどなかった。逆に，肉眼判定十の PCでは

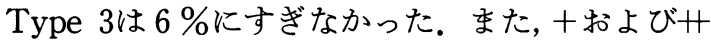
の PCの特徵として Type 2の粒度分布を示すも のが多くあり, +の60\%, +の50\%が Type 2で あった。粒度分布のタイプと凝集能との関係を Fig. 2に示した。トロンビン $(1 \mathrm{U} / \mathrm{m} l)$ に対する凝

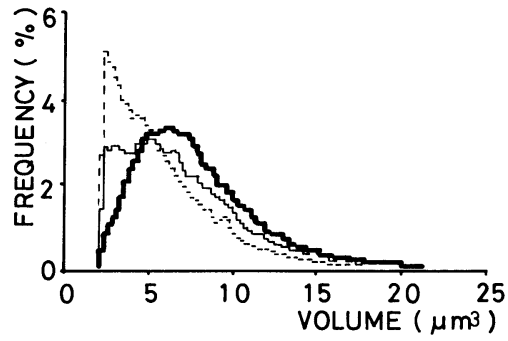

Fig. 1 Platelet size distribution curves of PCs containing clumps.

-: Type 1, - : Type 2, -.. Type 3. Minimum threshold level was set at $2.5 \mu \mathrm{m}^{3}$.

Table 1 Relation between number of clumps and size distribution type

\begin{tabular}{c|r|r|r|c}
\hline \multirow{2}{*}{ Clumps } & \multicolumn{4}{|c}{ Size distribution type } \\
\cline { 2 - 5 } & 1 & 2 & 3 & Total \\
\hline- & 18 & 2 & 0 & 20 \\
+ & 11 & 20 & 2 & 33 \\
+ & 9 & 18 & 9 & 36 \\
H & 1 & 8 & 22 & 31 \\
\hline
\end{tabular}

20 PCs with no clumps(-) and 100 PCs with clumps were classified. 


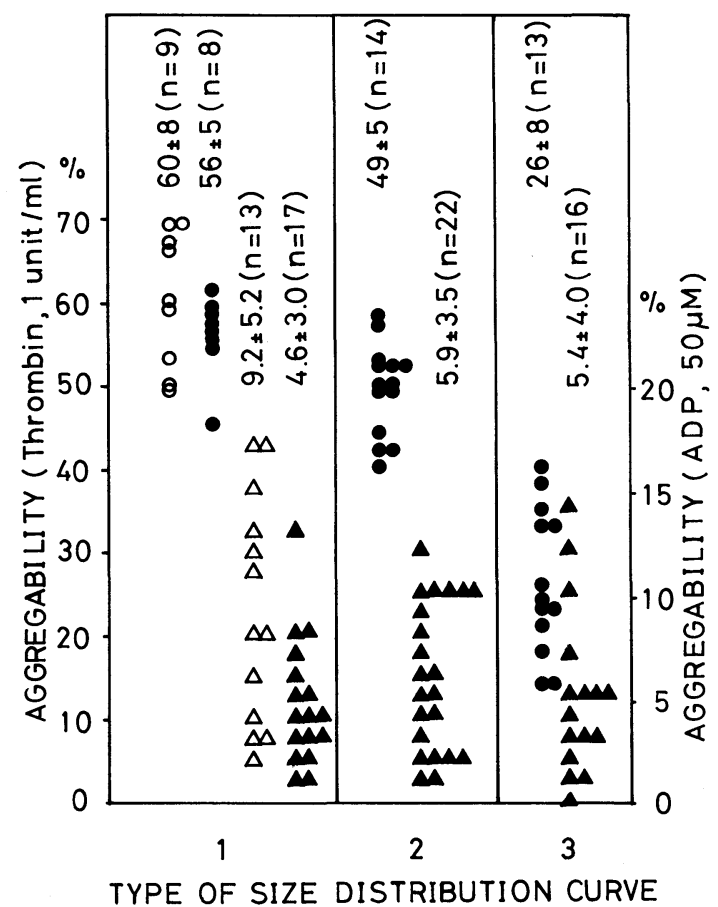

Fig. 2 Relation between type of size distribution and aggregability.

$\bigcirc$, Aggregability to $1 \mathrm{U} / \mathrm{m} l$ thrombin, $\triangle, \Delta$ : Aggregability to $50 \mu \mathrm{M}$ ADP, $\bigcirc, \triangle$ : PCs which do not contain clumps, $\mathbf{\Delta}$ : PCs which contain clumps. Numbers shown above symbols are mean values $\pm S D$.

集能は粒度分布が異常になるにつれ低下した．特 に Type 3では低下が大きく, $26 \pm 8 \%$ と低值を示 した.しかし，凝集塊のある PCでも Type 1では $56 \pm 5 \%$ と凝集塊のないPCの $60 \pm 8 \%$ と比べ差

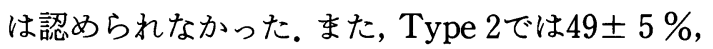
と若干の低下はあるものの，大きな低下は認めら れなかった。

次に，凝集塊の除去を目的として Microaggregate Filter に凝集のあるPCを通したところ 粒度分布や血小板数に影響せずに凝集塊を取り除 くことができた(data not shown).さらに, Table 2 に示したごとく, 調製後, 穏やかな水平回転擋拌 により保存したPCを, Microaggregate Filter に 通したが, 透過前後の $5 \mu \mathrm{M}$ 及び $50 \mu \mathrm{M}$ ADP, 0.05 $\mathrm{U} / \mathrm{m} l$ 及び $1 \mathrm{U} / \mathrm{m} l$ トロンビンに対する凝集能, 血 小板数, MPV，さらに粒度分布 (data not shown)
Table 2 Effects of microaggregate filtration on platelet functions

\begin{tabular}{|c|c|c|c|}
\hline & & Before & After \\
\hline $\begin{array}{l}5 \mu \mathrm{M} \text { ADP } \\
\text { aggregation }\end{array}$ & $(\%)$ & $13 \pm 5$ & $14 \pm 6$ \\
\hline $\begin{array}{l}50 \mu \mathrm{M} \text { ADP } \\
\text { aggregation }\end{array}$ & (\%) & $41 \pm 11$ & $41 \pm 11$ \\
\hline $\begin{array}{l}0.05 \mathrm{U} / \mathrm{ml} \\
\text { Thrombin } \\
\text { aggregation }\end{array}$ & $(\%)$ & $42 \pm 11$ & $44 \pm 12$ \\
\hline $\begin{array}{l}1 \mathrm{U} / \mathrm{m} l \\
\text { Thrombin } \\
\text { aggregation }\end{array}$ & (\%) & $65 \pm 3$ & $66 \pm 3$ \\
\hline MPV & $\left(\mu \mathrm{m}^{3}\right)$ & $8.4 \pm 0.6$ & $8.4 \pm 0.6$ \\
\hline $\begin{array}{l}\text { Platelet } \\
\text { concentration }\end{array}$ & $\left(\times 10^{4} / \mu l\right)$ & $142 \pm 17$ & $144 \pm 18$ \\
\hline
\end{tabular}

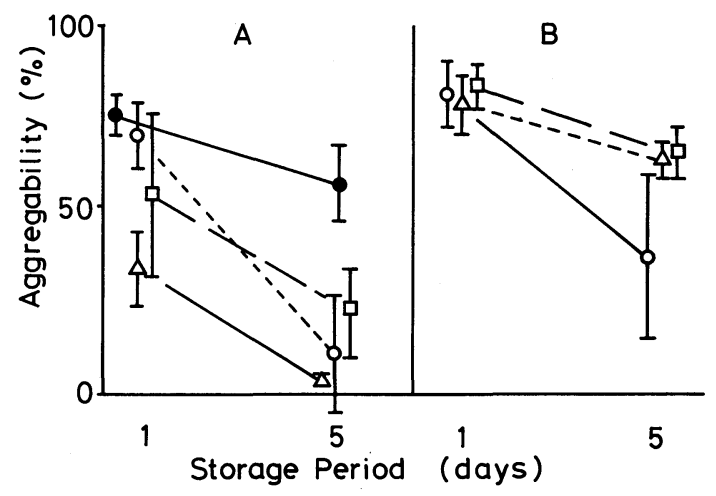

Fig. 3 Aggregability changes with storage

A : single agonist, $: 1 \mathrm{U} / \mathrm{m} l$ thrombin, $\bigcirc: 0.05$ $\mathrm{U} / \mathrm{m} l$ thrombin, $\triangle: 50 \mu \mathrm{M}$ ADP, $\square: 20 \mu \mathrm{g} / \mathrm{m} l$ collagen. B : multiple agonists, $\bigcirc: 50 \mu \mathrm{M} \mathrm{ADP}+$ $0.05 \mathrm{U} / \mathrm{m} l$ thrombin, $\triangle: 50 \mu \mathrm{M} \mathrm{ADP}+20 \mu \mathrm{g} / \mathrm{m} l$ collagen, $\square: 20 \mu \mathrm{g} / \mathrm{m} l$ collagen $+0.05 \mathrm{U} / \mathrm{m} l$ thrombin.

にも変化はみられなかった。

なお, 以上のように粒度分布が正常な Type 1の 血小板は，その機能を良く保持していた事から， このような血小板を穏やかな水平回転擋挥で 5 日 目まで保存し，各種凝集惹起剤に対する凝集能を 洗浄血小板を用いて測定した. $50 \mu \mathrm{M} \mathrm{ADP}, 20 \mu \mathrm{g} /$ $\mathrm{m} l$ コラゲン及び $0.05 \mathrm{U} / \mathrm{m} l$ トロンビンに対する 凝集能は保存とともに減少し， 5 日後には $50 \mu \mathrm{M}$ $\mathrm{ADP}$ に対する凝集能は $4 \pm 2 \%, 20 \mu \mathrm{g} / \mathrm{m} l$ コラー ゲンに対する凝集能は $22 \pm 13 \%, 0.05 \mathrm{U} / \mathrm{m} l$ トロ ンビンに対する凝集能は $13 \pm 16 \%$ と低值を示し 
た。しかしながら, $1 \mathrm{U} / \mathrm{m} l$ トロンビンに対する凝 集能は 5 日後でも $57 \pm 11 \%$ と高値を示した（Fig. 3 -A).さらに, 単独ではほとんど㠜集を引き起こさ なかった凝集炭起剤を組合せて 2 種類を同時に添 加すると, $50 \mu \mathrm{M} \mathrm{ADP} \mathrm{と} 20 \mu \mathrm{g} / \mathrm{m} l$ コラーゲンで は $63 \pm 5 \%, 20 \mu \mathrm{g} / \mathrm{m} l$ コラーゲンと $0.05 \mathrm{U} / \mathrm{m} l$ ト ロンビンでは $65 \pm 7 \%, 50 \mu \mathrm{M}$ ADP と $0.05 \mathrm{U} / \mathrm{m} l$ トロンビンは $37 \pm 22 \%$ と 5 日保存したものでも高 い凝集能を有する結果が得られた (Fig. 3-B).

\section{考 察}

日本では採血量は $200 \mathrm{ml}$ の場合が多く,さらに, 採血バッグの透過性がすぐれている ${ }^{13) 14}$ など種々 の条件が諸外国とは異なっている。そのためか, $\mathrm{PC}$ 中の血小板数も少なく，また $\mathrm{pH}$ も諸外国よ り高い ${ }^{10)}$ 。それゆ光，製造条件が難しい。例えば， 高い pH は大量にルーチンとして PCを調製する 場合には，凝集塊が発生しやすくなる要因の $1 つ$ と考学られている15). 保存に拈いても, 高い $\mathrm{pH}$ と いら条件下では，穏やかに擋汼保存を行えば，血 小板の機能になんら影響を及ぼさないが，激しい 擋拌を行らと血小板が破壊される ${ }^{16)}$. 赤十字血液 センターでは凝集塊発生の原因とその発生の防止 法を模索しているが末だ完全な方法はない1115). 一 方，このような凝集塊のある PCが使用できるか 否かに関する研究も未だない。

そこで我々はこのような凝集塊のある PC や血 小板が破壊されたような PCを使用できるのか否 か，また，それを簡単に知る方法があるのかを検 討した。その結果，血小板の大きさや形態の変化 を表すものと考えられている血小板の粒度分布が 血小板機能とも密接に関係していることが明らか となり，簡便な品質管理手段となり得ることを認 めた。凝集塊の見られた PCでは粒度分布の正常 なものと異常なものとがあり, それが凝集塊の数 と相関していた，凝集には血小板の破壊を伴うも のとそこまで至っていないものの 2 種類が存在す ると考えられる。そして正常な粒度分布を示すむ のは血小板破壊が少ないと考兄られた。

今回はさらに粒度分布と凝集能の関係を見てみ たが，高濃度 $(1 \mathrm{U} / \mathrm{m} l)$ トロンビンに対する凝 集も粒度分布 Type 3 では約 $26 \%$ と他の Type
(Type 1; 56\%, Type 2；49\%) よりかなり低值 を示した。このことから，粒度分布異常を示した 血小板の機能低下はかなり激しいものと思われ る. ADP 凝集能は垂直回転 $6 \mathrm{rpm}$ の保存条件では 粒度分布のタイプによる差が見られなかったが， これはADP 凝集能は激しい擋找により明らかな 絶対值の低下が起こり, 粒度分布の正常な血小板 でも保存による低下が激しいためと考えられる。 穏やかな擋汼（水平回転 $50 \mathrm{rpm}$ ）を行えば，より 高い凝集能を維持していた（Table 2, Fig. 3).

粒度分布が Type 1の血小板が正常な血小板と 言えるかどうか。また，それと血小板の凝集能の 関係をさらに詳しく知るため，PCで 5 日間室温 保存し, その粒度分布が Type 1 の血小板の凝集 能を調べてみた。高濃度トロンビンや凝集惹起剤 の複合による刺激に対しそれらの血小板は高い凝 集能を示した。この結果は生体内での血小板凝集 が種々の因子の相互作用により起こることを考え 合せると，粒度分布が Type 1 の正常な血小板な ら, 5 日保存した血小板でも生体内で有効に機能す る可能性を示唆するものと考兄られる．諸外国の 有効期間と比して日本の PC の有効期間はあまり にも短く，有効期間をさらに延長することも望ま れる。

Holme らは激しい擋拌で保存したPCの血小 板粒度分布では dispersion が増加し, それが輸血 後の血小板回収率の低下とよく相関することを報 告している ${ }^{17)}$. さらに形態と viability がよく相関 することもしられている1819). 従って小粒子の出 現したType 3 の粒度分布を示した PCは輸血に 使用しても効果を示さないと考えられる。

しかし, 正常な粒度分布, Type 1の PC は凝集 塊があっても Microaggregate Filterを用い凝集 塊を除去すれば輸血に使用できる可能性が示唆さ れた. Microaggregate Filterは穏やかな擋拌に より保存状態を良くして保存した反応性に富むと 考えられる血小板を通しても機能などには全く影 響を及ぼしていない結果は，このフィルターの有 用性を示唆しているものと思われる。今後, in vivo での血小板の有効性についても検討して行 かなければならないであろら。 


\section{結語}

凝集塊のある $\mathrm{PC}$ 中の血小板は著しく破壊され 機能を傷害されているものと，そうでないものが ある。それは粒度分布を測定すれば正確にみわけ ることができるがその凝集塊の数によっても扮㧤 まかに分けることが出来ることがわかった，血小 板の粒度分布は血小板機能を良く反映しており， また操作法自体も簡便であることから，PCの品 質管理に使用すれば非常に有用であることがわ かった.

さらに，粒度分布が正常な血小板は凝集塊が あっても Microaggregate Filter を通せば血小板 の機能を損うことなく輸血できることがわかっ た。

\section{文献}

1）武部道和, 西田一雄, 外山陽之助, 清水 勝：血 液バックの变更に伴なら濃縮血小板血漿製剤 （PC）の凝集塊発生に関する検討。日輸血会誌, $32: 533-538,1986$.

2) Aster, R.H. and Jandl, J.H.: Platelet sequestration in man. I. Methods. J. Clin. Invest., 43 : 843-855, 1964.

3) Aster, R.H.: Effect of acidification in enhancing viability of platelet concentrates. Current Status. Vox Sang., $17: 23-27,1969$.

4) Pert, J.H., Zucker, M.B., Lundberg, A., Yankee, R. and Hendersen, E.: Recent advances in preparation of platelet concentrates from ACD and CPD blood. Vox Sang., 13:119-126, 1967.

5) Pool, J.G.: The effect of several variables on cryoprecipitated factor VIII (AHG) concentrates. Transfusion, $7: 165-167,1967$.

6) Slichter, S.J. and Harker, L.A.: Preparation and storage of platelet concentrates II. Storage variables influencing platelet viability and function. Br. J. Haem., 34 : 403-419, 1976.

7) Mourad, N.: A simple method for obtaining platelet concentrates free of aggregates. Transfusion, $8: 48,1968$.

8）松田利夫, 坂内 誠, 召田明子, 宇田川武男, 清 水 勝, 笹川 滋: 血小板保存条件の検討 II. 血
小板周囲の $\mathrm{pH}$ の影響。日輸血会誌, $29: 704$ $-706,1983$.

9）坂野立子, 田口淳一, 足達光男, 伊藤 等, 岩田 卓也，佐藤三吉，松永信夫：有効時間延長による 濃縮血小板血漿供給状況の变化. 血液事業, 9 ： 224-225, 1986.

10）松田利夫，坂内 誠，笹川 滋：濃縮血小板血漿 の保存について一保存液及び擋汼の影響一。日輸 血会誌, 29：331-339, 1983.

11) Born, G.V.R. : Aggregation of blood platelets by adenosine diphosphate and its reversal. Nature, 194 : 927-929, 1962.

12) Legrand, C., Dubernard, V. and Caen, J.: Platelet aggregation: Its relation with ADP. induced fibrinogen binding to platelets and ADP-related membrane enzyme activities. Eur. J. Biochem., 142 : 465-471, 1984.

13) Sasakawa, S. and Tokunaga, E.: Physical and chemical changes of ACD-preserved blood: A comparison of blood in glass bottles and plastic bags. Vox Sang., 31: 199-210, 1976.

14) Wallvik, J. and Ákerblom, O.: Platelet concentrates stored at $22^{\circ} \mathrm{C}$ need oxygen. The significance of plastics in platelet preservation. Vox Sang., 45 : 303-311, 1983.

15）宇多正行, 岡田英俊, 内藤俊二, 石居昭夫, 西崎 太計志：CPD 液を用いた濃縮血小板血漿の調整 法と保存法についての検討。血液事業, $6: 139$ $-147,1983$.

16) Bannai, M., Mazda, T. and Sasakawa, S.: The effects of $\mathrm{pH}$ and agitation on platelet preservation. Transfusion, 25 : 57-59, 1985.

17) Holme, S., Vaidja, K. and Murphy, S.: Platelet storage at $22^{\circ} \mathrm{C}$ : Effect of type of agitation on morphology, viability, and function in vitro. Blood, 52: 425-435, 1978.

18) Kunicki, T.J., Tuccelli, M., Becker, G.A. and Aster, R.H.: A study of variables affecting the quality of platelets stroed at "room temperature". Transfusion, 15: 414-421, 1975.

19) Murphy, S. and Gardner, F.H.: Platelet strage at $22^{\circ} \mathrm{C}$ : Role of gas transport across plastic containers in maintenance of viability. Blood, 46 : 209-218, 1975. 